\title{
Participatory Rural Appraisal (PRA) untuk Pengembangan Desa Wisata di Pedukuhan Pucung, Desa Wukirsari, Bantul
}

\author{
Bambang Hudayana, Pande Made Kutanegara, Setiadi, Agus Indiyanto, Zamzam \\ Fauzanafi, Mubarika Dyah F.N., Wiwik Sushartami, dan Mohamad Yusuf \\ Departemen Antropologi, Fakultas Ilmu Budaya, Universitas Gadjah Mada \\ Korespondensi: bambang.hudayana@ugm.ac.id
}

\begin{abstract}
A Community service program (PkM) carried out by the Department of Anthropology, Faculty of Cultural Sciences, Gadjah Mada University in 2018 took place in Pucung Hamlet, Wukirsari Village, Bantul, which aims to develop Pedukuhan Pucung as a tourism village through participatory methods. In the implementation of this PkM, the participatory method that is introduced is the PRA (participatory rural appraisal) that researchers could act as facilitators and could directly facilitate citizens to recognize and utilize participatory methods to develop a CAP (Community Action Plan) which would later become a tourist village development plan. At the end of the implementation of this program, the CAP has successfully compiled the development of a Pucung tourism village based on local culture and it was also agreed to create a tourism village development organization and to select several local facilitators. Further, the PkM team will still provide assistance to the sustainability and implementation of the CAP of the Pucung Tourism Village.
\end{abstract}

Keywords: Pucung Hamlet, tourism village, PRA (participatory rural appraisal), CAP (Community Action Plan)

\begin{abstract}
Abstrak
Kegiatan program pengabdian kepada masyarakat $(\mathrm{PkM})$ yang dilakukan oleh Departemen Antropologi, Fakultas Ilmu Budaya, Universitas Gadjah Mada pada tahun 2018 ini mengambil lokasi di Pedukuhan Pucung, Desa Wukirsari, Bantul, yang terkait dengan pengembangan Pucung sebagai desa wisata secara partisipatoris. Dalam pelaksanaan PkM ini, metode partisipatoris yang dikenalkan adalah metode PRA sehingga peneliti dapat bertindak sebagai fasilitator dan langsung dapat memfasilitasi warga dalam mengenal dan memanfaatkan metode partisipatoris untuk menyusun CAP (Community Action Plan), yang nantinya akan menjadi program pengembangan desa wisata. Pada akhir pelaksanaan program ini telah berhasil disusun CAP pengembangan Desa Wisata Pucung yang berbasis budaya lokal dan juga disepakati untuk membentuk kepengurusan organisasi pengembangan desa wisata dan pemilihan beberapa fasilitator lokal. Dalam pengembangan selanjutnya, tim PkM masih akan melakukan pendampingan terhadap keberlanjutan dan pelaksanaan CAP pengembangan Desa Wisata Pucung.
\end{abstract}

Kata kunci: Pedukuhan Pucung, desa wisata, PRA (participatory rural appraisal), CAP (Community Action Plan) 


\section{Pendahuluan}

Praktisi kebudayaan merupakan agen yang sangat penting dalam pelestarian dan pengembangan kebudayaan. Hal ini karena merekalah yang memiliki kapasitas, krediblitas, dan bahkan kepentingan atas kebudayaan yang mereka lestarikan. Dewasa ini, para praktisi kebudayaan telah terjun dalam pengembangan kebudayaan lokal di tingkat desa dengan tujuan mewujudkan desa wisata. Mereka melestarikan berbagai kearifan lokal yang tidak lain adalah pengetahuan lokal di bidang lingkungan hidup, mata penncaharian hidup, kuliner, kesenian, dan berbagai adat kehidupan sosial di desa. Wisatawan datang untuk mengapresiasi dan memahami berbagai kearifan lokal tersebut.

Peran para praktisi kebudayaan yang memiliki mandat untuk melestarikan pengetahuan lokal itu dapat menentukan maju-mundumya desa wisata. Mereka termotivasi untuk mampu mengembangkan kekhasan budaya lokal di tingkat desa dan mereproduksinya untuk kepentingan pemajuan desa wisata. Mereka juga bersaing untuk melestarikan berbagai budaya lokal dan bahkan berupaya untuk menghidupkan kembali kebudayaan lokal yang tergerus oleh arus modernisasi dan globalisasi. Peran mereka menjadi penting dalam pengembangan wisata yang berpihak kepada kaum lemah. Hampton (2003) mencatat bahwa pariwisata skala kecil di Yogyakarta memiliki daya respons yang kuat atas ancaman meluasnya industri wisata skala besar pada era globalisasi.

Para praktisi kebudayaan telah membuktikan keberhasilannya dalam memajukan desa wisata sehingga desa wisata ini populer dan selalu dikunjungi oleh para wisatawan. Mereka berhasil dalam menghidupkan kembali, merevitalisasi, dan meningkatkan fungsinya untuk kemudian melakukan penguatan para praktisi kebudayaan di tingkat desa agar mereka dapat membuat program pengembangan desa wisata secara partisipatoris berbasis pada kebudayaan yang dimiliki. Peran kami sejalan dengan amanah antropologi terapan, yaitu tidak hanya melakukan kajian kritis atas berbagai masalah pembangunan, tetapi juga melakukan kerja advokasi dan pendampingan (Hudayana, 2017:9). Dengan kata lain, kami mempromosikan program aksi secara partisipatoris agar masyarakat desa lebih berdaya, seperti dapat menyusun rencana aksi komunitas atau CAP (Community Action Plan) di bidang pengembangan desa wisata yang bersumber dari kekuatan budaya lokalnya.

Praktisi atau pegiat kebudayaan yang dimaksud dalam artikel ini adalah mereka yang mempunyai kepentingan dan kegiatan untuk melestarikan pengetahuan lokal (local knowledge) yang luas cakupannya, bukan hanya yang berkaitan dengan kesenian, adat-istiadat, pertukaran sosial, kepercayaan, dan ritual, melainkan juga yang berkaitan dengan adaptasi seperti mata pencaharian, makanan (kuliner), herbal, tata lingkungan, dan perumahan.

Melalui penelitian aksi yang bersifat partisipatoris, metode penguatan kapasitas para pegiat kebudayaan tidak dalam bentuk pelatihan di kelas dengan meningkatkan pengetahuan dan keterampilan yang bersifat normatif, misalnya menghafalkan modulmodul fasilitasi. Metode pembelajaran tersebut sangat tidak partisipatoris karena mensterilkan mereka dengan permasalahan yang muncul di komunitasnya dan tidak melibatkan komunitas untuk ikut memecahkan masalah yang dihadapi. Dalam penelitian ini, metode partisipatoris yang diberikan adalah metode PRA karena dengan metode ini, 
peneliti bertindak sebagai fasilitator dan langsung memfasilitasi warga dalam mengenali dan memafaatkan metode partisipatoris untuk menyusun CAP yang nantinya akan menjadi program pengembangan desa wisata.

Sejauh ini, pemerintah terus melakukan upaya pemajuan kebudayaan nasional Indonesia agar menjadi akar pembangunan di berbagai sektor pemerintahan. Dengan disahkannya Undang-Undang Nomor 5 Tahun 2017 tentang Pemajuan Kebudayaan, para praktisi kebudayaan juga mempunyai harapan baru agar pemerintah berperan aktif dalam melakukan perlindungan, pengembangan, pemanfaatan, serta pembinaan kebudayaan, tidak hanya kebudayaan nasional dan daerah, tetapi juga kebudayaan lokal yang berada di tingkat desa.

Para praktisi kebudayaan di tingkat desa berharap pemerintah bukan hanya ikut memfasilitasi pengembangan sarana dan prasarana pemajuan kebudayaan seperti ikut memfasilitasi warga memiliki perangkat musik tradisional, gedung kesenian, dan sanggar budaya, melainkan juga mendukung upaya penguatan organiasi dan SDM-nya. Selain itu, mereka juga menyadari pentingnya dukungan pemerintah dan pemangku kepentingan (stakeholders) untuk pengembangan desa wisata berbasis budaya lokal secara partisipatoris sehingga mereka mampu secara mandiri untuk mengelola kebudayaan lokal dan melestarikan serta memanfaatkannya untuk tujuan peningkatan kesejahteraan.

Gagasan pengembangan kebudayaan lokal secara partisipatoris akan terwujud apabila para praktisi kebudayaan lokal juga memahami konsep pemberdayaan masyarakat secara partisipatoris dan dapat melaksanakannya sepenuh hati. Oleh karena itu, dengan semangat populis, para dosen pada Departemen Antropologi, Fakultas Ilmu Budaya UGM terpanggil untuk ikut mempromosikan pengembangan kebudayaan lokal secara partisipatoris terhadap desa atau dusun yang memiliki potensi tersebut. Riset aksi ini kemudian membidikkan perhatian pada bagaimana menjalin kerja sama dengan komunitas dan mengawal proses penyusunan program desa wisata secara partisipatif.

\section{Tujuan}

- Memperkenalkan kepada para praktisi kebudayaan di tingkat desa tentang konsep dan aplikasi metode pemberdayaan masyarakat secara partisipatoris dengan menggunakan model PRA (participatory rural appraisal).

- Mengawal para praktisi kebudayaan dan warga masyarakat dalam mengaplikasikan metode PRA untuk penyusunan program desa wisata sebagai CAP (Community Action Plan).

\section{Manfaat}

Secara akademis, penelitian aksi ini dapat menghasilkan strategi pemberdayaan secara partisipatoris yang efektif untuk pengembangan desa wisata berbasis pada potensi lokal. Paling tidak, artikel ini memberikan pemahaman tentang bagiamana metode partisipatoris diimplementasikan dan tergambar kekurangan serta kelebihannya.

Adapun secara praktis, penelitian aksi ini dapat memfasilitasi praktisi kebudayaan dan khususnya warga desa dalam mengembangkan desa wisata berbasis potensi budaya yang dimiliki melalui tersusunnya CAP dan rencana aksinya. Artikel ini menunjukkan 
bahwa masyarakat desa yang mengaplikasikan PRA untuk pengembangan desa wisata terbukti dapat dengan mudah menyusun CAP yang operasional dan partisipatif.

\section{Kerangka Konsep}

Partisipasi menjadi elemen penting dalam penyelenggaraan pemerintahan dan pembangunan pada era demokrasi (Gaventa, 2005) dan pada arena itu diperlukan metode yang efektif untuk menumbuhkan partisipasi masyarakat yang tinggi. Dalam agenda pembangunan desa, salah satu metode itu adalah PRA (participatory rural appraisal). PRA merupakan perpanjangan dan penerapan dari pemikirian, pendekatan, dan metode antropologi, terutama menyangkut konsep mengenai pembelajaran yang fleksibel di lapangan, nilai penting dari observasi-partisipasi, pentingnya pendekatan (rapport), pembedaan cara pandang etik (cara pandang peniliti) dan emik (cara pandang anggota komunitas), serta validitas dari pengetahuan lokal (Chambers, 1994:955).

Digabungkan dengan pendekatan dan metode lain, seperti activist participatory research dan rapid rural appraisal, PRA menjadi semacam "himpunan pendekatan dan metode yang memungkinkan masyarakat desa untuk berbagi, mengembangkan, dan menganalisa pengetahuan mereka mengenai hidup dan kondisi mereka sendiri, untuk perencanaan dan aksi" (Chambers, 1994:953). Salah satu metode dari puluhan metode yang dikembangkan melalui PRA adalah participatory planning (perencanaan secara partisipatoris), yang disertai penganggaran (budgetting), implementasi, dan monitoring. Melalui metode ini, masyarakat lokal mempersiapkan perencaan mereka sendiri, pendanaan, jadwal, melakukan aksi, serta melakukan monitoring dan evaluasi. Proses inilah yang disebut dan menghasilkan CAP (Community Action Plan).

Melalui metode PRA, masyarakat desa bukan lagi sebagai objek yang menerima program dari atas (top-down), melainkan menjadi subjek pembangunan yang merancang program pembangunan dari bawah (bottom-up) dengan terus aktif dalam proses perencanaan, penentuan skala prioritas program, penganggaran, pelaksanaan, dan pemanfaatan hasil pembangunan yang dikendalikan di tingkat desa. Partisipasi warga yang tinggi dalam proses pembangunan skala desa menjadikan program dapat dilaksanakan berbasis pada keswadayaan dan dapat lebih berhasil guna kesejahteraan mereka.

PRA merupakan metode penelitian aksi yang dikembangkan untuk meningkatkan partisipasi masyarakat dalam pembangunan. Robert Chambers menegaskan bahwa PRA memungkinkan orang desa (baca: masyarakat) dapat mengungkapkan dan menganalisis situasi mereka sendiri serta secara optimal merencanakan dan melaksanakan tekat itu di desanya sendiri (Mikkelsen, 2011:67). Dalam PRA, masyarakat desa berperan aktif dalam pemetaaan masalah sosial dan penyebabnya, peta jalan untuk memcahkan masalah, dan kemudian menuangkan menjadi program, dukungan anggaran, serta implementasinya berbasis pada kerja sama, keswadayaan, dan kemandirian masyarakat. PRA juga menjadi instrumen yang tepat untuk penilaian atas kebutuhan masyarakat di tingkat lokal (Mueller, 2010:1).

Posisi peneliti dalam PRA adalah sebagai fasilitator, yaitu orang yang memudahkan masyarakat untuk melakukan penelitian aksi tersebut. Melalui partisipasi yang tinggi, warga masyarakat yang terlibat dalam PRA dapat aktif dalam setiap kegiatan kelompok, 
misalnya pengumpulan data, analisis data, perumusan program, anggaran, dan detail kegiatan, serta implementasinya. Karena bertindak sebagai fasilitator, kegiatan PRA dapat dikatakan berhasil jika kelompok warga dapat aktif dan terus termotivasi untuk menghasilkan CAP serta melaksanakannya secara partisipatif.

PRA merupakan metode yang sangat tepercaya untuk program pemberdayaan masyarakat (Sinha, 1997; Mikkelson, 2011). Beberapa studi telah menunjukkan efektivitas metode ini. Studi Olofson (1985), misalnya, menunjukkan bahwa PRA dapat dipakai untuk program pelestarian hutan berbasis komunitas. Das (2012) telah menggunakan PRA untuk mewujudkan pengelolaan hutan secara partsipatoris sehingga mewujudkan penghidupan masyarakat desa yang berkelanjutan. PRA juga telah dipakai untuk program pengurangan risiko bencana di Philipina (Pante dkk., 2013). Bahkan, metode ini dapat dipakai untuk kepentingan penelitian ilmiah, misalnya memetakan pengetahuan lokal dan kebutuhan untuk mengidentifikasi masalah sosial. Mueller et.al. (2010), misalnya, menggunakan PRA untuk memahami pengetahuan etnoekologi dan biodiversitas tumbuhan di aras lokal.

Sebagai instrumen pemberdayaan masyarakat yang diharapkan dapat memecahkan masalah melalui CAP, PRA yang diaplikasikan pada program pengembangan desa wisata harus memiliki relevansi dengan permasalahan dari desa wisata selama ini. Permasalahannya bukan hanya berkaitan dengan kekurangan para praktisi kebudayaan dalam menyusun CAP secara partisipatoris, melainkan juga masih miskinnya elemenelemen kebudayaan lokal dalam pengembangan desa wisata. Akibatnya, desa wisata tidak menghadirkan paket wisata yang bernuansa kultural, tetapi sekadar bernuansa desa atau tradisional sehingga banyak desa wisata melahirkan paket-paket wisata yang seragam (homogen), miskin keunikan, dan keaslian.

Selain didorong untuk mampu memetakan potensi budaya lokalnya, masyarakat juga didorong untuk mampu mereproduksinya untuk kepentingan pengembangan desa wisata. Tidak semua potensi budaya itu dapat dikembangkan karena desa wisata yang bernuansa budaya bukan sekadar untuk pelestarian budaya yang ada, melainkan juga dapat menjadi daya tarik wisata dan memberikan keuntungan secara ekonomis bagi masyarakat desa. Oleh karena itu, dalam penyusunan CAP secara partsipatoris, warga diajak untuk memetakan potensi budayanya dan memetakan rencana bisnis yang masuk akal serta dapat dilaksanakan sesuai dengan kekuatan modal sosial dan materialnya.

\section{Kelompok Sasaran}

Pelatihan metode penelitian partisipasi dengan menggunakan PRA diarahkan untuk memperkuat kapasitas para pegiat kebudayaan di tingkat desa. Mereka adalah para pengelola usaha kuliner lokal, penangkar burung langka, pengelola istana penangkaran burung, perajin wayang kulit, seniman karawitan, tokoh masyarakat, dan budayawan desa. Kelompok sasaran dipusatkan di Pedukuhan Pucung, Desa Wukirsari, Kecamatan Imogiri, Kabupaten Bantul. Hal ini karena Pedukuhan Pucung yang terdiri atas enam dusun kecil sedang berusaha untuk membangun desa wisata berbasis pada kekayaan budayanya. Oleh karena itu, mereka sangat berharap dapat menjalin kerja sama dengan kelompok-kelompok warga di desa dan pihak pemerintah desa. 


\section{Pengenalan Metode Pra untuk CAP Desa Wisata}

Berpijak dari berbagai masalah pembangunan desa wisata di Pucung, para fasilitator kemudian mendorong forum pelatihan dan workshop untuk menyimak pentingnya program pembangunan pariwisata di Pucung dan Wukirsari yang pada umumnya dilaksanakan secara partisipatoris. Fasilitator menyiapkan materi tentang isi dan arah pelaksanaan PRA sebagai salah satu metode partisipatoris. Secara konseptual, metode PRA diartikan sebagai sekumpulan pendekatan dan metode yang mendorong masyarakat pedesaan untuk ikut serta meningkatkan dan menganalisis pengetahuan mereka mengenai hidup dalam konteks kondisi mereka sendiri agar mereka dapat membuat rencana dan tindakan (Chambers,1994).

Dengan menggunakan konsep PRA itu, peserta workshop didorong untuk mengetahui manfaat PRA bagi pembangunan sosial yang visinya adalah pada terwujudnya kemandirian masyarakat dan sejumlah prinsip, misalnya mendorong program pembangunan dilaksanakan secara swadaya dan gotiong royong. Karena lebih menekankan praktik daripada pengetahuan, pelatihan mengarahkan peran narasumber dan khususnya fasilitator untuk memfasilitasi warga mempraktikkan PRA. Narasumber juga bukan orang yang banyak menceritakan tentang dirinya dan pengalamannya, melainkan membantu warga untuk memetakan kembali pengalamannya dari beberapa pengetahuan dan pengalaman narasumber dalam mempromosikan PRA serta memfasilitasi warga dalam membuat CAP. Dengan demikian, mereka bukan menggurui, melainkan memudahkan warga untuk memiliki motivasi yang tinggi dan mengaplikasikan PRA serta menyusun CAP yang partisipatif.

Setelah tersusun strategi penyampaian materi PRA, penelitian aksi ini memetakan kebutuhan pendamping sebagai agensi yang nantinya akan memfasilitasi warga. Pendamping atau dalam berbagai literatur pemberdayaan sering disebut sebagai organizer komunitas (community organizer [selanjutnya diringkas $\mathrm{CO}$ ]) mempunyai andil yang penting dalam menentukan keberhasilan program. Oleh karena itu, sejak awal, tim peneliti aksi ini mengidentifîkasi calon-calon $\mathrm{CO}$ di desa yang potensial untuk menjadi mitra pengenalan PRA dan penyusunan CAP desa wisata.

Di setiap klaster dusun selalu ada tokoh yang dapat diandalkan sebagai CO. Hal ini karena Desa Wukirsari telah lama menjadi desa binaan LSM besar seperti Dompet Duafa, Bina Swadata, dan IRE Yogyakarta. Mereka bekerja dengan para CO yang pernah di-training atau yang memang telah menunjukkan kapasitasnya sebagai CO yang dipercaya di desa. Penelitian aksi ini kemudian mengangkat $\mathrm{CO}$ yang bernama Ujang dan Agung. Ujang dipercaya oleh masyarakat karena ia sedang naik daun atas keberhasilannya dalam mengelola perpustakaan desa dan pernah menjadi CO di desa dari beberapa LSM yang sering memfasilitasi program pemberdayaan masyarakat, misalnya di bidang penanggulangan kemiskinan, bencana alam, dan pelestarian lingkungan. Ujang diminta menjadi CO dalam penelitian aksi ini dengan harapan mengikuti pelatihan dan workshop agar pascakegiatan tersebut mereka memiliki CAP yang dipakai sebagai acuan bersama dalam mengembangkan desa wisata. Untuk penyelenggaraan pelatihan PRA dan CAP di Pedukuhan Pucung, penelitan aksi ini kemudian memilih Agung karena ia telah menjadi CO untuk pengembangan Istana Penangkaran Burung (IPB). Agung bahkan menjadi inisiator dan sponsor untuk pengembangan IPB dan IPB telah beroperasi 
melayani wisata di kalangan anak-anak sekolah meskipun dalam pelaksanaanya masih mandek dalam hal peningkatan promosi paket wisata dan partisipasi warga. Agung bahkan berharap agar penelitian aksi ini berlokasi di kampungnya agar pembelajaran PRA dapat diaplikasikan untuk penyusunan CAP desa wisata Pucung. Dengan memiliki CO yang tepercaya dan memiliki motivasi yang tinggi dalam pembangunan desa wisata tersebut, penelitian aksi dapat meraih berbagai kemudahan dalam memperkenalkan PRA serta sasarannya dan kemudian juga meraih kepercayaan warga.

Target pelatihan dapat menyasar sebanyak 30 orang yang berasal dari Pedukuhan Pucung. Mereka diharapkan dapat memahami pentingnya PRA untuk penghasilkan CAP secara pratisipatoris di bidang pengembangan desa wisata berbasis pada budaya lokal. Terdapat enam kegiatan yang dilakukan tim peneliti untuk menyelenggarakan pengenalan PRA kepada pegiat kebudayaan, yakni sebagai berikut.

1. penyusunan materi pelatihan dan pelibatan pendamping lokal

2. pengenalan metode PRA untuk CAP desa wisata

3. pemetaan masalah dan kebutuhan untuk CAP desa wisata

4. penentuan prioritas progam CAP desa eisata

5. pelibatan warga dalam proses perbaikan CAP desa wisata

6. rencana keikutsertaan tim peneliti pada implementasi CAP desa wisata

\section{Penyusunan Materi Pelatihan Pelibatan Pendamping Lokal}

Sebelum terjun ke lapangan, peneliti aksi dan asisten peneliti merumuskan terlebih dahulu materi pelatihan serta rencana pendampingan. Dengan mengindahkan semangat pemberdayaan, pelatihan bukan diajarkan di kelas dengan mengajak partisipan pelatihan untuk mengenal konsep, metode PRA, dan berbagai contoh CAP yang dihasilkan dari PRA, melainkan mengajak partisipan untuk langsung berlatih mempraktikkan PRA dan menyusun CAP desa wisata. Pelatihan dengan melakukan praktik nyata itu lebih disukai para partisipan dan sesuai dengan orientasi penelitian aksi, yaitu lebih menghasilkan perubahan perilaku dan kebijakan daripada perubahan peta berpikir dan pengetahuan yang tidak aplikatif.

Pelatihan hari pertama dengan agenda pengenalan metode partisipatif akhirnya menyepakati untuk memanfaatkan pelatihan sebagai ajang untuk membangun program desa dengan mengutamakan kelompok warga yang terabaikan dalam pembangunan yang selama ini sering terjadi, seperti kelompok miskin, dan prinsip lainnya adalah memosisikan masyarakat sebagai pelaku, orang luar sebagai fasilitator, serta prinsip orientasi praktis, dalam artian diskusi komunitas yaitu memecahkan masalah dan mengembangkan kegiatan yang dapat diimplementasikan oleh masyarakat sendiri.

Dalam menunjukkan aplikasi metode partisipatif, fasilitator menerangkan bahwa metode ini pemah dipakai oleh Bambang Hudayana dkk. dari IRE Yogyakarta untuk menyusun renstra desa pariwisata Wukirsari tahun 2008. Namun, renstra itu tidak terlaksana secara maksimal. Hanya Pedusunan Giriloyo yang mengaplikasikan renstra tersebut, khususnya pengembangan wisata batik, dengan mendapatkan dukungan dana dari Australian Indonesian Partnership (2007-2008) untuk pengurangan risiko bencana.

Hudayana juga menunjukkan betapa sangat berisikonya melakukan pembangunan desa wisata dengan berbasis pada bantuan donor. Faktanya, meskipun dahulu sudah dapat 
dilaksanakan dengan pendekatan partisipatif dan keswadayaan, masyarakat gampang tegiur oleh bantuan. Akibatnya, program masyarakat malah sibuk mencari bantuan atau menerima tamu yang memberikan bantuan. Semangat keswadayaan masyarakat pun meluntur dan banyak program yang tidak dikerjakan karena masih menunggu bantuan.

Dalam workshop juga disampaikan ceramah dari Pande Made Kutanegara tentang pengalaman masyarakat Bali dalam mengembangkan desa wisata. Keberhasilan desa wisata di Bali sangat ditentukan oleh adanya orang yang ditokohkan, yang artinya didukung, digerakkan oleh tokoh yang tepercaya, dan tidak mencari profit atau keuntungan personal. Dengan demikian, warga sangat percaya kepada mereka dan dapat memastikan akan memperoleh keuntungan, bukan dijadikan alat kepentingan elite yang menjadi teladannya.

\section{Pemetaan Masalah dan Kebutuhan CAP Desa Wisata di Pedukuhan Pucung}

Forum diskusi PRA difasilitasi oleh para peneliti dan asisten peneliti untuk dilakukan pemetaan masalah kebutuhan desa wisata. Dalam memetakan masalah, mereka berhasil menunjukkan sejumlah masalah yang bersifat internal dan eksternal. Salah satu masalah internal adalah fakta bahwa Pedukuhan Pucung belum berkembang desa wisatanya meskipun wilayah ini memiliki segudang potensi budaya. Masalah internal timbul karena, pertama, tidak ada pemimpin yang mempersatukan warga, seolah-oleh setiap warga bekerja sendiri-sendiri dan saling bersaing dalam mempromosikan produk kerajinan, homestay, dan paket wisata lainnya. Kedua, warga tidak memiliki kapasitas yang memadai untuk mengembangkan kerja sama dan curiga terhadap munculnya tokoh yang nantinya justru akan menjadi pesaing warga dalam mengembangkan usaha di sektor pariwisata.

Forum diskusi juga berhasil memetakan masalah eksternal, yaitu pejabat pemerintah atau pihak pemerintah desa cenderung suka bekerja sama dengan tokoh di dusun yang sudah dikenal meskipun kurang kredibel. Mereka juga tidak memiliki renstra ataupun perencanaan dan visi pembangunan desa wisata.

Pada pemetaan masalah dan kebutuhan itu, forum diskusi mencatat sejumlah harapan meskipun belum menjadi keputusan bersama. Pertama, perlu ada semangat untuk membuat program secara partisipatif dengan selalu mendengarkan aspirasi dari bawah. Kedua, perlu melakukan pemetaaan potensi budaya dan melibatkan masyarakat untuk pengembangan potensi budaya. Ketiga, perlu adanya kemauan yang kuat dari setiap warga untuk membuat rumah dan kehidupan sehiari-hari sebagai sesuatu yang menarik untuk diapresiasi oleh warga setempat sebelum mereka menyusunnya menjadi program desa wisata yang mengundang tamu dari luar. Keempat, perlu adanya semangat membangun desa wisata secara swadaya.

\section{Pilihan Program Prioritas Cap Desa Wisata}

Setelah memahami pentingnya PRA sebagai instrumen untuk menyusun CAP, peserta kemudian percaya bahwa forum dapat membuat CAP pariwisata di Pedukuhan Pucung yang kredibel. Mereka memetakan berbagai usulan tentang rencana program desa wisata 
di Pucung. Dalam diskusi hari pertama dan kedua, forum menyebutkan programprogram unggulan sebagai berikut:

- wisata homestay;

- wisata kerajinan kulit dan bambu;

- wisata penangkaran burung dan air terjun;

- wisata kuliner lokal;

- wisata kesenian karawitan.

Setiap usulan program di atas dijabarkan oleh peserta forum tentang konteks relevansi, maksud dan tujuan, sasaran, bentuk kegiatan, partisipasi masyarakat, serta berbagai modal budaya yang sudah dimiliki oleh masyarakat. Dengan demikian, peserta dapat menunjukkan bahwa program yang mereka usulkan itu berbasis pada kekuatan dari dalam komunitas, bukan sebuah program yang sekadar meniru program lain yang sudah ada di desa wisata tetangga.

Peserta juga memiliki kesadaaran kuat bahwa program pengembangan wisata harus berakar pada kebudayaan yang ada di desa agar diapresiasi oleh wisatawan dan harus dikembangkan atas dasar keswadayaan serta partispasi masyarakat yang tinggi sehingga dapat meningkatkan kesejahteraan masyarakat secara luas. Mereka juga menilai bahwa banyak program yang diperkenalkan oleh para donor, dinas pemerintah, swasta melalui corporate social responsibility (CSR) dan LSM ke dalam wilayah Desa Wukirsari, tetapi program tersebut justru tidak sensitif dengan budaya lokal, yakni bukan memperkuat, melainkan memperlemah dan berimbas pada munculnya kelas-kelas sosial-ekonomi baru yang merusak struktur sosial-ekonomi yang sudah ada. Riyadi, peserta forum diskusi CAP, menyampaikan pesan yang menyatakan sikap kembali pada kekuatan budaya warga.

"Kami kecewa dengan program pemerintah yang tujuannya membangun desa wisata, tetapi implementasinya adalah memberikan bantuan pembangunan kioskios kerajinan. Akhirnya wisatawan datang tidak lagi masuk ke rumah-rumah para produsen kerajinan kulit. Mereka hanya masuk ke kios-kios tersebut untuk berbelanja, tidak mengenal dan menghayati kehidupan budaya lokal. Selain itu, akibatnya sebagian dari kios-kios itu dikuasai oleh orang luar yang tidak berurusan dengan budaya lokal."

Forum diskusi mencatat bahwa program-program dapat dibuat, tetapi harus benarbenar menggambarkan suasana desa yang sebenarnya. Misalnya, jika desa menawarkan wisata kesenian, warga desa aktif mengisi waktu dengan berkesenian karawitan, bukan diselenggarakan karena alasan untuk mencari turis. Warga harus mahir dalam menabuh gamelan dan menyanyi tembang Jawa jauh sebelum turis datang. Demikian pula warga selayaknya kembali ke rumah tradisional dan juga menempati rumah tersebut sehingga turis juga ikut menempati homestay yang benar-benar ditempati warga, bukan bangunan asing yang terpisah dengan tempat tinggal warga di desa. Para tamu juga datang ke desa untuk melihat kehidupan asli di desa, bukan kehidupan yang dibuat-buat hanya karena warga berkeinginan untuk menyambut turis yang mendatangkan uang.

Melalui peran fasilitator, forum akhirnya dapat menggali berbagai prinsip yang harus diindahkan dalam membangun desa wisata. Mereka, misalnya, mulai menghidupkan kembali seni-budaya yang pernah ada dan masih relevan untuk kehidupan masyarakat 
desa. Misalnya, mereka mengindentifikasi berbagai jenis kebiasaan orang desa dalam mencari tanaman liar untuk makan atau tanaman-tanaman langka tetapi berguna untuk ketahanan pangan, misalnya buah duwet. Oleh karena itu, sebelum mengundang banyak tamu, mereka mencatat pentingnya upaya menghidupkan tanaman tersebut.

Prinisip lainnya adalah tidak mengubah lanskap desa sehingga suasana desa tetap alami. Misalnya, jika hendak menikmati wisata air terjun, tamu harus berjalan kaki dari lokasi terminal ke lokasi air terjun. Kendaraan tamu tidak diperkenankan berhenti di bibir air terjun sehingga merusak pemandangan. Demikian pula jika hendak menikmati kawasan penangkaran burung langka, wisatawan harus berjalan kaki, bukan menaiki kendaraan sehingga mereka benar-benar melakukan wisata seperti orang desa. Selain itu, wisatawan juga diajak untuk belajar menangkar atau memberi pakan burung sehingga mereka dapat menghayati kebutuhan burung untuk bertahan hidup. Forum juga menyadari pentingnya orang desa harus berbenah menyiapkan desa wisata, sekali lagi bukan karena alasan untuk mencari turis, melainkan agar mereka dapat berwisata sendiri di desanya sehingga mereka bangga dengan lingkungan yang mereka jaga kebersihan, keindahannya, dan keamanannya. Oleh karena itu, warga percaya bahwa tanpa ada tamu pun, orang desa tetap merasakan manfaat dari sikap yang arif terhadap pelestarian lingkungan dan budaya di desanya.

Akhirnya, melalui diskusi dalam kegiatan PRA, para pegiat kebudayaan juga mencatat prinsip bahwa desa wisata harus dibangun untuk kesejahteraan bersama. Dengan demikian, partisipasi warga harus tinggi dan akses harus terbuka bagi semua warga untuk dapat mendapatkan manfaat secara ekonomi dan sosial, baik secara langsung maupun tidak langsung, dan keuntungan dari hadirnya tamu dapat digunakan untuk membiayai pembangunan komunitas.

Dalam pertemuan hari pertama dan kedua, forum diskusi sudah mempunyai pandangan yang sama tentang pentingnya pembangunan desa wisata, yakni dimulai dari terbangunnya pasar kuliner lokal yang dibuka setiap Minggu pagi. Kesepahaman itu muncul secara demokratis dan dari hasil pemetaan potensi. Hal itu karena forum memilih pasar kuliner berdasarkan musyawarah dan kaum perempuan dapat meyakinkan forum bahwa kulinerlah yang paling mudah membawa dampak multiplier terbangunnya desa wisata. Lewat kuliner, semua warga akan mudah terlibat hadir sebagai pedagang atau konsumen. Jika tidak dinikmati oleh wisatawan, minimal kuliner tetap dapat dinikmati oleh warga lokal. Karena jumlah peserta perempuan yang hadir lebih banyak daripada laki-laki, forum mudah menyetujui gagasan pengembangan pasar kuliner pada hari Minggu sebagai pintu masuk untuk memulai pembangunan desa wisata dan khususnya paket-paket wisata yang potensial untuk dikembangkan di wilayah Pucung.

Selain karena forum diskusi banyak dihadiri oleh perempuan, pengembangan pasar kuliner memang paling masuk akal untuk merajut kebersamaan antarwarga dalam membangun desa wisata. Jika pintu masuka program pengembangan pariwisata dimulai dari wisata burung langka, wayang, kerajinan bambu, atau homestay, program ini tidak akan pupuler karena hanya dinikmati oleh kelompok-kelompok warga yang sudah tersegmentasi berdasarkan tempat tinggal yang berlainan. Dengan menghadirkan kuliner lokal, semua kelompok warga dapat hadir. Selain itu, tamu yang datang juga dapat digiring untuk berkeliling desa dengan mengunjungi wisata burung langka, kerajinan kulit, dan seni budaya karawitan. 
Dengan menetapkan pengembangan desa wisata yang dimulai lewat pembangunan pasar kuliner, peserta perempuan pelatihan PRA dan penyusunan CAP merasa mendapat kepercayaan tinggi dalam pembangunan pariwisata. Mereka melakukan konsolidasi untuk menyosialisasikan program ke dusun dan komunitasnya. Mereka percaya bahwa kawan-kawan di dusunnya akan ikut berpartisipasi dalam pembangunan pasar kuliner karena mereka membutuhkan kegiatan relaksasi dan mencari makanan pada hari libur serta minimal dapat ikut menjadi pengunjung guna memeriahkan suasana pasar.

\section{Pelibatan Warga dalam Proses Perbaikan dan Rencana Implementsi CAP}

Pada pertemuan ketiga, setelah CAP terususun pada hari sebelumnya dan rancangan aksi mengarah pada satu kegiatan utama, yaitu pengembangan pasar kuliner, para peserta workshop berkumpul kembali untuk mengadakan sosialisasi hasil CAP kepada warga dan pemangku kebijakan atau birokrasi. Pada proses sosialisasi ini, warga diharapkan ikut terlibat dalam perbaikan CAP dan pelaksanaannya. Namun, sebelum proses sosialisasi dijalankan, peserta workshop bersepakat untuk terlebih dahulu membentuk struktur organisasi untuk kegiatan pasar kuliner. "Agar kita tidak dianggap gerombolan, diterima, dan diakui oleh perangkat desa," menurut Agung, salah satu peserta workshop, aktivis penangkaran Burung di Pucung. Untuk itu, melalui proses musyawarah, disepakati susunan kepengurusan sebagai berikut. Ketua 1 yang dipilih adalah Pak Riyadi, seorang perajin wayang, karena beliau dianggap punya relasi yang baik dengan warga dan perangkat. Ketua II adalah Agung, penangkar burung, yang dianggap mempunyai relasi luas dengan pihak luar dan penyandang dana. Sementara itu, untuk sekretaris adalah Gufron, bendahara adalah Siti, perlengkapan dan logistik adalah Eko Riswanto, humas dan dana usaha adalah Subardi dan Tuti, serta tim kreatif adalah Suprapti Ningsih dan Bariah.

Setelah kepengurusan terbentuk disepakati bahwa proses sosialisasi dengan warga akan dilakukan terus oleh pengurus dan sosialisasi akan dimulai bersamaan dengan meninjau lokasi yang direncanakan menjadi pasar kuliner. Sesampainya di lokasi, tidak banyak warga yang beraktivitas di sana. Sebagian besar hanya berlalu-lalang melewati jalan beraspal yang menghubungkan Desa Pucung dengan lokasi wisata lain seperti Becici dan wisata hutan pinus. "Setiap akhir pekan banyak orang melintasi jalan ini, sebagian besar wisatawan yang akan menuju Becici atau hutan pinus, makanya lokasi di sini tepat untuk membuat pasar kuliner. Nanti pasti banyak wisatawan bisa mampir ...” jelas Bu Siti, salah satu anggota kelompok kuliner Pucung.

Lokasi yang dipilih sementara berada di titik pusat Pucung yang berupa sawah dan lapangan dengan status tanah miliki negara. Lapangan akan difungsikan sebagai lahan parkir, sedangkan lokasi pasar kuliner berada di tengah sawah. Antara gubuk satu dan yang lain akan dihubungkan dengan menggunakan jembatan-jembatan kecil dari kayu.

Karena hanya sedikit warga yang dapat diajak berbincang soal rencana aksi membuat pasar kuliner, para peserta workshop mengajak untuk mengunjungi rumah Pak Riyadi atau ketua 1 dari kelompok ini. Di rumah Pak Riyadi disepakati untuk melakukan sosialisasi kepada warga keesokan harinya. Pada kesempatan pertemuan di rumahnya, Pak Riyadi mengutarakan bahwa selama ini di Pucung banyak potensi wisata dan SDM 
yang memadai. Melalui pembuatan CAP, mereka tersadar akan potensi dan kekuatan SDM tersebut dan mampu menggagas rencana aksi yang memadai.

Pada hari berikutnya, para pengurus yang telah ditentukan secara musyawarah mufakat untuk melakukan sosialisasi Rencana Aksi "Pasar Minggu" di IPB dengan melibatkan seluruh elemen masyarakat lintas gender dan generasi. Respons tamu undangan terhadap rencana aksi pasar minggu sangat positif. Muncul kesadaran bersama untuk membawa Rencana Aksi ini di tingkat desa karena menyadari pentingnya gerakan dari bawah ataupun atas. Dari hasil sosialisasi tersebut, muncul kesepakatan untuk melakukan diskusi mingguan tentang "Pasar Minggu”. Selain itu, dari kegiatan sosialisasi tersebut, tersusun berbagai usulan terkait dengan pengembalian kebudayaan-kebudayaan nenek moyang yang mulai ditinggalkan oleh generasi sekarang, seperti pentas musik gagakan atau gamelan di tengah sawah sebagai pentas seni untuk menghibur petani yang sedang bekerja di lahannya

Demikianlah capaian-capaian yang diperoleh oleh tim rencana aksi 'Pasar Minggu' ketika melakukan sosialisasi CAP terhadap warga yang lain. Dari proses dan hasilnya, pelajaran yang dapat diperoleh adalah melalui proses yang partisipatoris dan organisasi yang tepercaya, warga dapat menerima CAP yang telah disusun. Lebih dari itu, warga juga ikut aktif menyumbangkan ide untuk pelaksanaan CAP yang sukses, dengan menambahkan rancangan kegiatan lain yang lebih menarik, kontekstual, dan implementatif. Hal ini juga menunjukkan bahwa para pegiat kebudayaan yang telah mendapatkan pelatihan PRA dan menghasilkan CAP sudah dapat menjadi fasilitator untuk warga lainnya sehingga rancangan aksi mereka diterima dan bahkan dapat dikembangkan bersama-sama dengan melibatkan warga lain dalam skala yang lebih luas.

\section{Rencana Keikutsertaan Tim Peneliti pada Implementasi CAP}

Tersusunnya dan tersosialisasinya CAP desa wisata di Pucung secara partisipatif belum menjamin CAP tersebut dapat diimplimentasikan dengan baik. Tim peneliti dan panitia CAP menyadari bahwa implementasi CAP harus berjalan sesuai dengan rencana dan berbuah baik bagi pelestarian kebudayaan dan peningkatan kesejahteraan masyarakat.

Panitia CAP memandang tim peneliti masih perlu bekerja lebih lanjut untuk melakukan pendampingan sekaligus ikut mempromosikan desa wisata di Pucung. Kerja tim peneliti, antara lain, adalah membantu warga membuat film promosi dan mendesain tata ruang pasar kuliner serta memperkuat kesadaran komunitas tentang pentingnya penguatan kebudayaan lokal sebagai elemen penting dalam pengembangan desa wisata di Pucung. Tim peneliti membuat rencana pendampingan atas dasar kesukarelaan dan siap diundang oleh panitia CAP untuk ikut mengimplementasikannya. Dengan ikut terlibat dalam implementasi, tim peneliti terlibat aktif dan keberhasilan penelitian aksi itu tergantung pada niat serta keterlibatan aktif dalam mengawal proses perencanaan sampai dengan implementasi program.

\section{Kesimpulan}

Pelibatan sarjana antropologi pada pengenalan PRA untuk penyusunan CAP desa wisata merupakan bagian dari kerja antropologi terapan, khususnya antropologi aksi. 
PRA merupakan metode yang mampu meningkatkan partisipasi warga komunitas dalam pembangunan desa wisata. Peningkatan partisipasi menjadi jalan keluar menuju terwujudnya pemberdayaan masyarakat.

PRA menjadi elemen penting dalam proses perencanaan pembangunan yang menghasilkan CAP desa wisata. Peran antropolog menjadi relevan dalam memfasilitasi warga untuk mengenal dan mempraktikkan CAP desa wisata karena secara metodologis, antropolog terbiasa menggunakan metode induktif dan melakukan skala penelitian yang bersifat mikro dan induktif untuk memetakan masalah serta menemukan tesis penelitian. Dengan cara induktif, antropolog menggali data lapangan melalui wawancara mendalam dan dalam kegiatan PRA, tugas mereka adalah membuka akses kepada warga untuk bercerita, memetakan masalah, serta merumuskan rencana. Kegiatan PRA dapat dilaksanakan oleh sarjana antropologi dan sekaligus sebagai kegiatan untuk melakukan kerja-kerja antropologi aksi secara partisipatif.

Aplikasi PRA dan penyusunan CAP desa wisata di Pucung telah berhasil membangun kesadaran yang kuat pada warga bahwa PRA menjadi alat bagi mereka untuk mewujudkan keberdayaan. Dengan menggunakan PRA, warga dapat lebih cermat dalam memetakan potensi budaya untuk program pariwisata. Selain itu, dengan PRA, mereka dapat membangun program yang lebih aspiratif dan menggerakkan partisipasi masyarakat yang tinggi. Dengan PRA, mereka sadar bahwa banyak program pembangunan yang masuk ke desa tetapi miskin partisipasi dan warga tidak dapat mewujudkannya karena tidak memiliki model yang disusun dari pengalaman yang memadai. CAP yang dibuat oleh orang Pucung yang dihasilkan dengan memakai metode PRA telah meningkatkan semangat warga untuk membangun desa wisata berbasis pada potensi budayanya.

\section{Daftar Pustaka}

Chambers, Robert. (1994). "The Origins and Practice of Participatory Rural Appraisal” dalam World Development, 22 (7): 953-969.

Das, Nimai. (2012). "Agricultural \& Applied Economies Association Impact of Participatory Forestry Program on Sustainable Rural Livelihoods: Lessons From an Indian Province" dalam Applied Economie Perspectives and Policy, 34(3): 428-453.

Gaventa, John. (2005). "Enam Sasaran Proposisi Menuju Tata Pemerintahan Daerah Partisipatoris" dalam Sugeng Bahagio dan Rusdi Tagaroa (eds.) Orde Partisipasi. Jakarta: Perkumpulan Prakarsa, hlm. 1-21.

Hampton, P. Mark. (2003). "Entry Points for Local Tourism in Developing Countries: Evidence from Yogyakarta, Indonesia" dalam Geografiska Annaler Sériés B Human Geography, 85 (2): 85-101.

Hudayana, Bambang. (2017). Pemberdayaan Masyarakat, Bunga Rampai Antropologi Terapan. Yogyakarta: Pustaka Pelajar.

Mikkelsen, Britha. (2011). Metode Penelitian Parttisipatoris dan Upaya Pemberdayaan. Jakarta: Yayasan Pustaka Obor Indonesia.

Mueller, Jocelyn G. dkk. (2010)."Evaluating Rapid Participatory Rural Appraisal as an Assessment of Ethnoecological Knowledge and Local Biodiversity Patterns" dalam Conservation Biology, 24(1): 140-150. 
Olofson, Harold. (1985). "Rapid Rural Appraisal For Social Forestry in a Philippine Community" dalam Journal PhiUippine Quartely Culture and Society, 13 (3): 198220.

Pante, Bemadeth Laurelyn dkk. (2013). "Participatory Action Research in Disaster Preparedness and Community Reconstruction" dalam Philippine Sociological Review, 61(2): 428-453.

Sinha, K. Prabhakar. (1997). "In Defence of Paticipatory Rural Appraisal” dalam Economies and Political Weekly, 32 (13): 672. 